\title{
An unknown migration route of the 'globally threatened' Aquatic Warbler revealed by geolocators
}

\author{
Volker Salewski $\cdot$ Martin Flade $\cdot$ Anatolii Poluda $\cdot$ Grzegorz Kiljan • \\ Felix Liechti $\cdot$ Simeon Lisovski $\cdot$ Steffen Hahn
}

Received: 25 September 2012/Revised: 30 October 2012/Accepted: 8 November 2012/Published online: 1 December 2012

(C) Dt. Ornithologen-Gesellschaft e.V. 2012

\begin{abstract}
The globally-threatened Aquatic Warbler (Acrocephalus paludicola) breeds in Europe and spends the northern winter in sub-Saharan West Africa. We attached 30 geolocators to breeding birds in the central Ukraine in 2010. Three geolocators which collected data from the autumn migration were recovered in 2011. They revealed a previously-unknown migration route via southern Europe to stopover sites in south-western France and Spain. In West Africa, one bird spent some time well south of known non-breeding areas. For the conservation of some Aquatic Warbler populations, protection of hitherto unknown stopover sites in southern Europe and Africa may be crucial.
\end{abstract}

Keywords Acrocephalus paludicola . Conservation . Flyway $\cdot$ Wintering grounds

Communicated by F. Bairlein.

\section{Salewski $(\bowtie)$}

Behavioural Biology, University of Osnabrück,

Barbarastr. 11, 49076 Osnabrück, Germany

e-mail: volker.salewski@biologie.uni-osnabrueck.de

M. Flade

Abt. Großschutzgebiete und Regionalentwicklung,

Landesamt für Umwelt, Gesundheit und

Verbraucherschutz Brandenburg, Tramper Chaussee 2,

16225, Eberswalde, Germany

e-mail: Martin.Flade@LUGV.Brandenburg.de

\section{A. Poluda}

Ukrainian Society for the Protection of Birds,

Schmalhausen Institute of Zoology,

National Academy of Sciences of Ukraine,

Bogdan Khmelnitsky Str. 15, Kiev-30 MSP 01601, Ukraine

e-mail: polud@izan.kiev.ua

\section{Zusammenfassung}

Geolokation deckt unbekannten Zugweg des global bedrohten Seggenrohrsängers auf.

Der global bedrohte Seggenrohrsänger (Acrocephalus paludicola) brütet in Europa und überwintert in Westafrika. Wir rüsteten 201030 Seggenrohrsänger in einem Brutgebiet in der Zentral-Ukraine mit Geolokatoren aus. Drei Geolokatoren, die Daten vom Herbstzug aufnahmen, wurden 2011 zurückgewonnen. Sie zeigten einen bis dahin unbekannten Zugweg der Seggenrohrsänger durch Südeuropa zu den ersten Hauptrastgebieten in Südfrankreich und Spanien an. In Westafrika hielt sich ein Vogel weit südlich der bekannten Überwinterungsgebiete auf. Für den Schutz der Seggenrohrsänger könnte es daher bedeutend sein, die noch unbekannten Rastgebiete in Südeuropa und Afrika zu berücksichtigen.

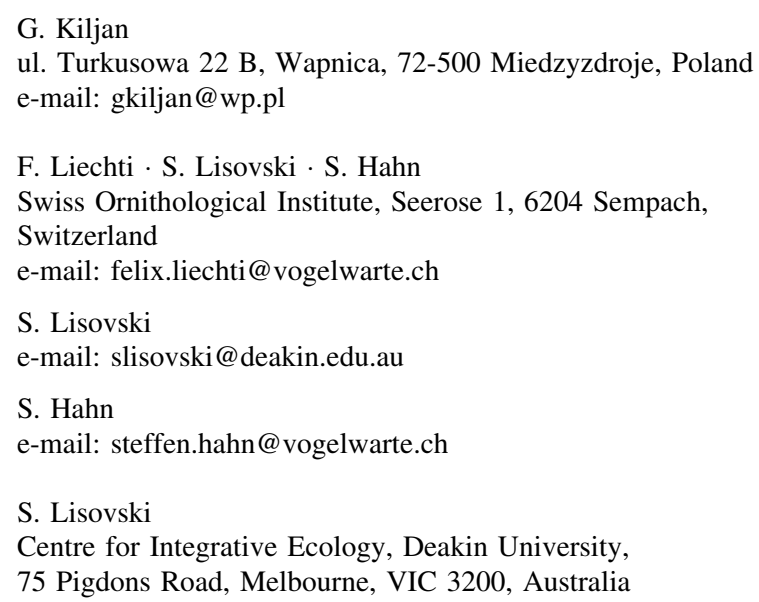




\section{Introduction}

The Aquatic Warbler (Acrocephalus paludicola) is the only globally-threatened passerine species that breeds in mainland Europe (BirdLife International 2004). Aquatic Warblers spend the northern winter in sub-Saharan West Africa (Schäffer et al. 2006), but the two recently discovered wintering sites in the Djoudj area of northern Senegal, and in the Inner Niger Delta of Mali, are unlikely to hold the entire world population during the non-breeding season (Flade et al. 2011; Poluda et al. 2012). In 2010, we attached geolocators to 30 Aquatic Warblers in the Supii marshes, Ukraine. The aims of this study were to test the feasibility of the geolocator method for this species, and to investigate migration routes, stopover sites and non-breeding areas used by this population.

\section{Methods}

Application of geolocators

In July 2010, male Aquatic Warblers were captured with mist-nets in the Supii marshes, central Ukraine $\left(50.42^{\circ} \mathrm{N}\right.$, $31.73^{\circ} \mathrm{E}$ ). All birds were ringed and the body mass recorded. Thirty birds were equipped with a geolocator with a c. 5-mm-long light guide (SOI-GDL2, Swiss Ornithological Institute), and 16 birds were only ringed to serve as a control group. The geolocators were attached on the rump using a leg-loop harness (Rappole and Tipton 1990) made from VMQ silicone O-rings (Johannsen AG, Switzerland). All geolocators started measuring light levels on 10 July 2010 with an interval of $5 \mathrm{~min}$. The weight of the geolocators including the harness ranged from 0.60 to $0.67 \mathrm{~g}$ (mean: $0.63 \pm 0.02 \mathrm{~g} \mathrm{SD}$ ). For 29 birds (the body mass of one bird was not taken) the geolocators added between 4.6 and $5.7 \%$ additional weight to the body mass (mean: $12.4 \pm 0.6 \mathrm{~g} \mathrm{SD})$ at the time of capture. Therefore, the additional mass of the geolocators was below the values for which Naef-Daenzer et al. (2001) and Schmaljohann et al. (2012) could find no significant effect on body condition, manoeuvrability, and range-use in small passerines equipped with similar devices. To retrieve the geolocators, the breeding area was checked for singing males in May 2011. All ringed birds located were captured, body mass recorded, the ring number noted and geolocators retrieved.

\section{Data analysis}

We converted recorded sunlight intensities into geographical positions using the "threshold method" implemented in the R-package GeoLight (Lisovski and Hahn 2012).
Positions were calibrated using light intensity recordings of 8-10 days after instrumentation when the birds were still at the breeding site (in-habitat calibration, Lisovski et al. 2012). Sun elevation angles in combination with the light intensity threshold (three arbitrary values above the night baseline) for this location ranged from -0.69 to -0.75 . Therefore, we used $-0.7^{\circ}$ for all recordings to estimate latitude assuming that habitat use is similar during the annual cycle (Flade et al. 2011). Subsequent positions where the birds would have had to travel at $>100 \mathrm{~km}$ per hour were considered unrealistic and not included into the analyses and figures $(55,26$, and $67 \%$ removed for birds 1 , 2 and 3 respectively).

Stationary periods were defined as consecutive measurements where the differences in day/night lengths and in the time of solar midnight/noon changed within the same absolute magnitude as at the breeding site $( \pm 35$ and \pm 12 min respectively). Only locations where a bird stayed for at least four days were considered as stopover sites. Standard ellipses to indicate the area of stationary periods were calculated using the $\mathrm{R}$ package siar (Jackson et al. 2011).

\section{Results}

Six $(20 \%)$ Aquatic Warblers fitted with geolocators were recaptured in 2011, but two of them had lost the device. Abraded feathers on the legs of one of the latter birds suggested that this loss happened recently. The number of recaptures from the control group was also six $(37.5 \%)$. The difference in the recapture rate of the two groups was not significant $(p>0.05)$ when all six recaptures of the geolocator group were considered (Pearsson's $\chi^{2}$-test: $\chi^{2}{ }_{1}=0.93$, $p=0.33$ ), nor when only the five birds that apparently migrated successfully with a geolocator were taken into account (Pearsson's $\chi^{2}$-test: $\chi^{2}{ }_{1}=1.46, p=0.23$ ). In 2011, the body mass of the four birds with geolocators ranged from 12.5 to $13.0 \mathrm{~g}$ (mean $=12.9 \mathrm{~g} \pm 0.25 \mathrm{SD}$ ). This was in the range of males captured without geolocators $(n=16$, range $11.0-13.5 \mathrm{~g}$, mean $=12.4 \mathrm{~g} \pm 0.64 \mathrm{SD}$ ) indicating that the geolocators had no negative effect on the body mass of returning birds although numbers were too low for a statistical comparison.

One geolocator stopped collecting data 8 days after it started to operate, the others (hereafter birds 1, 2 and 3) on the 18,11 and 8 September respectively. Leaving the breeding area between the 21 to the 25 of July (Table 1), the birds started to migrate on a south-westerly and later westerly course via the Balkan Peninsula and Italy to major stopover areas in south-western France or on the Iberian Peninsula (Fig. 1a, c). Density calculations of clustered positions (longitudinal separation into $3^{\circ}$ sections) 
Table 1 Characterization of the use of main staging sites by Aquatic Warblers during autumn migration in 2010 as depicted in Fig. 1

\begin{tabular}{lllllc}
\hline Bird & $\begin{array}{l}\text { Staging } \\
\text { site }\end{array}$ & Longitude & Arrival & Departure & $\begin{array}{c}\text { Stopover } \\
\text { duration }\end{array}$ \\
\hline 1 & 1 & $32.49^{\circ} \mathrm{E}$ & & 21. Jul & \\
& 2 & $6.63^{\circ} \mathrm{W}$ & 12. Aug & 20. Aug & 8 \\
& 3 & $16.72^{\circ} \mathrm{W}$ & 22. Aug & 31. Aug & 9 \\
& 4 & $3.56^{\circ} \mathrm{W}$ & 09. Sep & & $>9$ \\
2 & 1 & $31.58^{\circ} \mathrm{E}$ & & 25. Jul & \\
& 2 & $1.74^{\circ} \mathrm{W}$ & 08. Aug & 13. Aug & 5 \\
& 3 & $8.72^{\circ} \mathrm{W}$ & 15. Aug & 28. Aug & 13 \\
& 4 & $12.11^{\circ} \mathrm{W}$ & 30. Aug & 09. Sep & 10 \\
3 & 1 & $31.85^{\circ} \mathrm{E}$ & & 23. Jul & \\
& 2 & $1.66^{\circ} \mathrm{W}$ & 9. Aug & 12. Aug & 4 \\
\hline
\end{tabular}

Longitudes are medians derived according to the geolocator localizations. (1: breeding site, 2-4: stopover sites)

indicated short stays of 2-3 days on the Balkan Peninsula and southern Italy (exact site determination hampered by scattered data, Fig. 1b) which were too short as being considered as stopover sites according to our definition.

The three birds spent 8,5 and 4 days on the first main stopover site (Table 1) before turning south towards Africa on 20, 13 and 12 August, respectively. Birds 1 and 3 headed directly to sub-Saharan Africa, whereas bird 2 spent another 13 days at a stopover site at the south-western tip of the Iberian Peninsula or in western Morocco (Fig. 1c). In Africa, the logger of bird 3 failed. Birds 1 and 2 stopped for a while at longitudes of about $16.72^{\circ} \mathrm{W}$ and $12.11^{\circ} \mathrm{W}$ respectively (Table 1; Fig. 1). There, the logger of bird 2 stopped collecting data after 10 days. Bird 1 resumed migration after 9 days, but changed its direction abruptly to an easterly course and reached a longitude of about $03.56^{\circ} \mathrm{W}$ (Fig. 1c) after 8 days on the 9 September. There the logger stopped collecting data 9 days later.

\section{Discussion}

Despite the low sample size, our data revealed new insights into the autumn migration of Aquatic Warblers. Previous studies suggested migration routes along the Atlantic coast of Belgium and The Netherlands into France (de By 1990; Schulze-Hagen 1991). However, our results indicate that populations of south-eastern Europe may use a route via the Balkan Peninsula and Italy to first main stopover areas in Western Europe.

There is a large spatial variance in our data, probably caused by variable shading which can result in a bias towards shorter days (i.e., to more southerly positions here) and strongly fluctuating positions (Lisovski et al. 2012). Differences between the true day-lengths along the
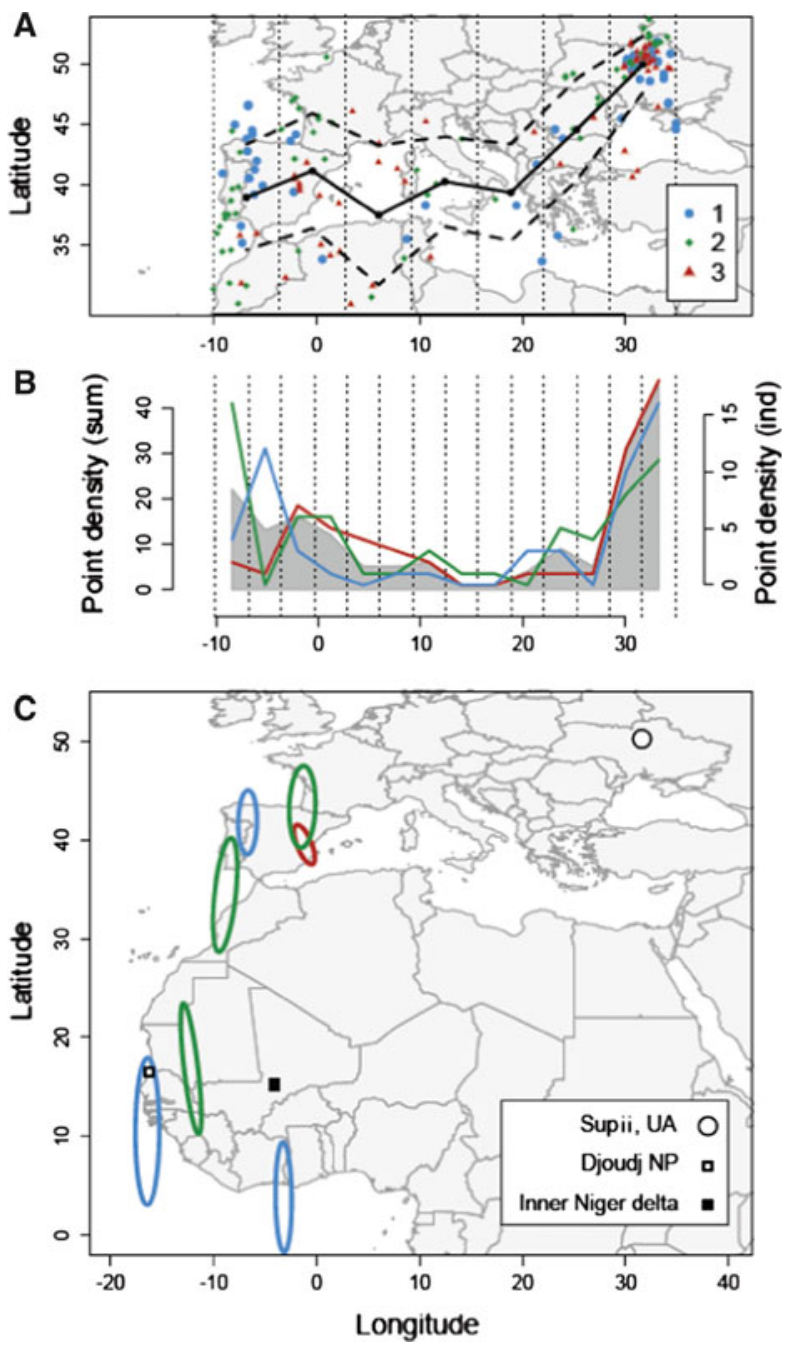

Fig. 1 Autumn migration pattern of three Aquatic Warblers as revealed by geolocators. The three individuals are depicted by colours. a Migration route from Ukrainian breeding site to the first major stopover sites in the western Mediterranean. Shown is the mean latitude (solid line) and the standard deviations of the positions clustered in $6^{\circ}$ longitude sections. b Density of calculated positions, clustered in $3^{\circ}$ longitude sections for all individuals (grey) and separately. c Major stopover sites (ellipses) with a staging period of at least 4 days, the breeding area (Supii marshes) and the two known main non-breeding staging areas in and around Djoudj National Park, northern Senegal, and the Inner Niger Delta in Mali

northern standard deviation line (Fig. 1a) and the measured day-lengths on the first migration leg show a median deviation of $27.8 \mathrm{~min}(\mathrm{SD} \pm 25 \mathrm{~min})$. Deviations of this magnitude were recorded in woodland (Lisovski et al. 2012). As it is unlikely that Aquatic Warblers rest in such dense habitats we can conclude that higher shading in comparison to the breeding site might result in a shift of calculated positions southwards. Therefore, the majority of recorded day lengths must have been gathered south of the northern standard deviation line. 
The localizations of bird 1 in Africa indicate a migration route distinctly south of the known wintering sites. This could be due to high variance induced by the approaching equinox. However, these data, as well as a record from northern Ghana (Hedenström et al. 1990), indicate that this area may be used by Aquatic Warblers, although the area was not expected to offer suitable habitats according to a remote sensing analysis (Buchanan et al. 2011).

This study has implications for the conservation of Aquatic Warblers. Julliard et al. (2006) point out that France provides the major stopover sites and should therefore play a key role in undertaking conservation measures which is most likely correct for populations in north-central Europe. However, we show that there is also a migration route to the western Mediterranean south of the Alps and identifying and protecting unknown stopover sites on this route may be important for the conservation of south-eastern populations. Previously we considered that there are population-specific wintering sites and that the conservation of specific sites may be crucial for the conservation of different populations. The data retrieved from bird 1 suggest that migrating birds use different staging sites within sub-Saharan Africa. Therefore, wetlands close to the West African coast may play a key role for the conservation of Aquatic Warblers not only for populations spending the northern winter there, but also for populations that migrate through the area to reach wintering sites elsewhere. Furthermore, wintering areas may be found further south than previously expected.

Acknowledgments We are grateful to N. Znakovaite-Rodriguez and E. Bächler for the help with the production of the geolocators and with data analyses. A. Berndt, B. Gießing, O. Ilucha and I. Legeyda helped with field work in the Ukraine. G. Kirwan, J. Korb and L. Serra helped with literature search. H. Schmaljohann and an anonymous reviewer improved a previous version of the manuscript. D. Franklin improved our English. For the support of the project we thank the Ukrainian Society for the Protection of Birds/BirdLife Ukraine, the Royal Society for the Protection of Birds and the O.M.H. Schmidt-Felsche Foundation.

\section{References}

BirdLife International (2004) Birds in Europe: population estimates, trends and conservation status. BirdLife International, Cambridge

Buchanan GM, Lachmann L, Tegetmeyer C, Oppel S, Nelson A, Flade M (2011) Identifying the potential wintering sites of the globally threatened Aquatic Warbler Acrocephalus paludicola using remote sensing. Ostrich 82:81-85

de By RA (1990) Migration of Aquatic Warbler in Western Europe. Dutch Birding 12:165-181

Flade M, Diop I, Haase M, Le Nevé A, Oppel S, Tegetmeyer C, Vogel A, Salewski V (2011) Distribution, ecology and threat status of the Aquatic Warbler Acrocephalus paludicola wintering in West Africa. J Ornithol 152(Suppl 1):S129-S140

Hedenström A, Bensch S, Hasselqvist D, Ottosson U (1990) Observations of Palaearctic migrants rare to Ghana. Bull BOC 110:194-197

Jackson AL, Inger R, Parnell AC, Bearhop S (2011) Comparing isotopic niche widths among and within communities: SIBERStable Isotope Bayesian Ellipses in R. J Anim Ecol 80:595-602

Julliard R, Bargain B, Dubos A, Jiguet F (2006) Identifying autumn migration routes for the globally threatened Aquatic Warbler Acrocephalus paludicola. Ibis 148:735-743

Lisovski S, Hahn S (2012) GeoLight-processing and analysing lightbased geolocator data in R. Methods Ecol Evol (in press)

Lisovski S, Hewson CM, Klaassen RHG, Korner-Nievergelt F, Kristensen MW, Hahn S (2012) Geolocation by light: accuracy and precision affected by environmental factors. Methods Ecol Evol 3:603-612

Naef-Daenzer B, Widmer F, Nuber M (2001) A test for effects of radio-tagging on survival and movements of small birds. Avian Sci 1:15-23

Poluda A, Flade M, Foucher J, Kiljan G, Tegetmeyer C, Salewski V (2012) First confirmed connectivity between breeding sites and wintering areas of the globally threatened Aquatic Warbler Acrocephalus paludicola. Ringing Migr 27:57-59

Rappole JH, Tipton A (1990) New harness design for attachment of radio transmitters to small passerines. J Field Ornithol 62:335-337

Schäffer N, Walther BA, Gutteridge K, Rahbek C (2006) The African migration and wintering grounds of the Aquatic Warbler Acrocephalus paludicola. Bird Conserv Int 16:33-56

Schmaljohann H, Buchmann M, Fox JW, Bairlein F (2012) Tracking migration routes and the annual cycle of a trans-Sahara songbird migrant. Behav Ecol Sociobiol 66:915-922

Schulze-Hagen K (1991) Acrocephalus paludicola (Vieillot 1817)_ Seggenrohrsänger. In: Glutz v Blotzheim UN, Bauer KM (eds) Handbuch der Vögel Mitteleuropas, vol 12/I. AULA-Verlag, Wiesbaden, pp 252-291 